\title{
Aluminum induces cross-resistance of potato to Phytophthora infestans
}

\author{
Magdalena Arasimowicz-Jelonek • Jolanta Floryszak-Wieczorek • \\ Kinga Drzewiecka $\cdot$ Jagna Chmielowska-Bạk $\cdot$ Dariusz Abramowski $\cdot$ \\ Karolina Izbiańska
}

Received: 21 July 2013 / Accepted: 5 December 2013 / Published online: 18 December 2013

(C) The Author(s) 2013. This article is published with open access at Springerlink.com

\begin{abstract}
The phenomenon of cross-resistance allows plants to acquire resistance to a broad range of stresses after previous exposure to one specific factor. Although this stress-response relationship has been known for decades, the sequence of events that underpin cross-resistance remains unknown. Our experiments revealed that susceptible potato (Solanum tuberosum L. cv. Bintje) undergoing aluminum (Al) stress at the root level showed enhanced defense responses correlated with reduced disease symptoms after leaf inoculation with Phytophthora infestans. The protection capacity of $\mathrm{Al}$ to subsequent stress was associated with the local accumulation of $\mathrm{H}_{2} \mathrm{O}_{2}$ in roots and systemic activation of salicylic acid (SA) and nitric oxide (NO) dependent pathways. The most crucial Al-mediated changes involved coding of NO message in an enhanced $S$-nitrosothiol formation in leaves tuned with an abundant SNOs accumulation in the main vein of leaves. Al-induced distal NO generation was correlated with the overexpression of PR-2 and PR-3 at both mRNA and protein activity
\end{abstract}

Electronic supplementary material The online version of this article (doi:10.1007/s00425-013-2008-8) contains supplementary material, which is available to authorized users.

M. Arasimowicz-Jelonek ( $₫) \cdot$ J. Chmielowska-Bạk ·

K. Izbiańska

Department of Plant Ecophysiology, Faculty of Biology, Adam

Mickiewicz University, Umultowska 89, 61-614 Poznan, Poland

e-mail: marasimowicz@wp.pl; arasim@amu.edu.pl

J. Floryszak-Wieczorek · D. Abramowski

Department of Plant Physiology, Poznan University of Life

Sciences, Wołynska 35, 60-637 Poznan, Poland

K. Drzewiecka

Chemistry Department, Poznan University of Life Sciences,

Wojska Polskiego 28, 60-637 Poznan, Poland levels. In turn, after contact with a pathogen we observed early up-regulation of SA-mediated defense genes, e.g. $P R 1, P R-2, P R-3$ and $P A L$, and subsequent disease limitation. Taken together $\mathrm{Al}$ exposure induced distal changes in the biochemical stress imprint, facilitating more effective responses to a subsequent pathogen attack.

Keywords Aluminum - Biotic stress - Cross-resistance · Nitric oxide $\cdot S$-Nitrosothiols $\cdot$ Salicylic acid

\author{
Abbreviations \\ Al \\ Aluminum \\ Cu-FL Cupper-complex of 2-\{2-chloro-6-hydroxy- \\ 5-[2-methylquinolin-8-ylamino)methyl]-3-oxo- \\ 3H-xanthen-9-1\} benzoic acid \\ GSNOR $S$-Nitrosoglutathione reductase \\ $\mathrm{H}_{2} \mathrm{O}_{2} \quad$ Hydrogen peroxide \\ NO Nitric oxide \\ SA Salicylic acid \\ SAG Salicylic acid beta-glucoside \\ SNOs $\quad S$-Nitrosothiols
}

\section{Introduction}

Acid soils account for approximately $35 \%$ of arable land and are one of the most important limitations to plant production worldwide (Ryan et al. 2011). The restriction of crop growth and yield in soils with pH below 5.0 is mainly due to the formation and migration of phytotoxic aluminum ions $\mathrm{Al}^{3+}$. The primary target of phytotoxic $\mathrm{Al}^{3+}$ are plant roots, in which inhibition of root elongation and alternation of root architecture is observed even within minutes of the exposure (Doncheva et al. 2005). It is well documented that $\mathrm{Al}$ can disrupt many crucial physiological processes at 
both cellular and molecular levels, including nutrient and water uptake, intracellular transport, cell division and elongation, cell signaling and redox homeostasis (Barceló and Poschenrieder 2002).

Aluminum toxicity is not the only cause of crop production limitation. Plants are continuously exposed to a challenge by a broad range of stresses. In the course of evolutionary changes plants have developed mechanisms facilitating avoidance or active control of adverse environmental conditions. Effective plant defense responses are usually realized by the activation of specific signaling components with the expression of a battery of target genes, leading to tolerance or resistance mechanisms. An increasing body of evidence shows that plant exposure to one specific stress leads to acquired resistance to another stress. This phenomenon is known as cross-tolerance, cross-resistance or multiple-stress resistance and was shown for different types of stress (Steinberg 2012). For example, ozone exposure can induce resistance to virulent phytopathogenic Pseudomonas syringae strains in Arabidopsis and to tobacco mosaic virus in tobacco plants (Yalpani et al. 1994; Sharma et al. 1996). In barley, salt-induced osmotic stress was correlated with resistance to powdery mildew (Wiese et al. 2004), while in tomato drought stress enhanced resistance to Botrytis cinerea (Achuo et al. 2006). In relation to abiotic stresses it was demonstrated that wounding increased salt stress tolerance in tomato (Capiati et al. 2006), whereas cold acclimation can increase heat tolerance of winter rye, UV radiation enhanced drought tolerance in Pisum sativum and Triticum aestivum (Alexieva et al. 2001), heat shock improved tolerance of maize to heat, chilling, salt and drought (Gong et al. 2001).

Accumulating data strongly support that plant responses to both biotic and abiotic stresses are mediated by common signals, i.e. reactive oxygen and nitrogen species (ROS and RNS), calcium, salicylic acid (SA), jasmonic acid (JA) and abscisic acid (ABA) (Tippmann et al. 2006). The orchestration of these signals might be a central component controlling cross-tolerance, at least at the cellular level (Bowler and Fluhr 2000). On the other hand, there is evidence that the cross-tolerance phenomenon could be governed by an overriding signal molecule. For example, Asselbergh et al. (2008) suggested that ABA is involved in controlling a global shift between plant responses to abiotic and biotic stresses. In turn, strictly controlled generation of hydrogen peroxide $\left(\mathrm{H}_{2} \mathrm{O}_{2}\right)$ in transgenic tobacco (Cat1AS) that has a decreased ROS scavenging capacity resulted in both local and systemic induction of a pathogenesis-related protein and subsequently in inducible local resistance to bacterial pathogens (Chamnongpol et al. 1998). According to Bowler and Fluhr (2000), the cross-tolerance phenomenon occurs when the whole plant is exposed to the primary experience, or when systemic signals are also stimulated to ensure robust systemic resistance phenotypes. The long-distance modified signaling can lead to systemic acquired resistance (SAR) to a wide spectrum of pathogens and in relation to improved responses to abiotic stresses it is connected with systemic acquired acclimation (SAA). Interestingly, it has been reported that SAA involves a novel signal or a complex interaction between known signals distinct from pathogen-stimulated systemic acquired resistance, since SAA was transmitted in Arabidopsis mutants that perturb ABA, JA, SA, and SAR signaling (Rossel et al. 2007).

Although the importance of redox signals in networks that underpin cross-tolerance is strongly emphasized (Pastori and Foyer 2002), the role of nitric oxide (NO) in this stress response relationship remains puzzling. However, the evidence that $\mathrm{NO}$ is also involved in signaling defense during a plant-pathogen interaction and/or tolerance response to abiotic stress factors has been well documented in numerous experiments (for review see e.g.: Moreau et al. 2010).

In this study, we showed that aluminum exposure triggered distal signaling in potato plants, facilitating resistance to a subsequent attack by the oomycete pathogen Phytophthora infestans. Moreover, we provided evidence that the sequence of events that link perception and transduction of primary $\mathrm{Al}$-stress to biotic defense responses involve distal conversion of the NO message. To this end we monitored the metabolic status of $\mathrm{NO}$ at root-stem-leaves levels, including $\mathrm{NO}$ orchestration with $\mathrm{H}_{2} \mathrm{O}_{2}$ and SA after exposure to moderate aluminum stress enabling establishment of protection responses to the oomycete pathogen.

\section{Materials and methods}

Plant growth conditions and stress treatment

Sterile potato plants (Solanum tuberosum L.) of cv. Bintje, susceptible to Phytophthora infestans, derived from in vitro tissue culture (Plant Breeding and Acclimatization Institute, Research Division at Bonin, Poland) were grown hydroponically in plastic containers of $4 \mathrm{dm}^{3}$ in capacity. A modified Hoagland solution was used. After 3 weeks potato plants were transferred to a nutrient solution at $\mathrm{pH}$ 4.3 either supplemented with $\mathrm{AlCl}_{3}$ to a final concentration of $250 \mu \mathrm{M}$ (Al stress), or without $\mathrm{AlCl}_{3}$ (acidic control) for $48 \mathrm{~h}$. During the experiment the medium was aerated and after each week it was exchanged. The experiment was carried out in a phytochamber with $16 \mathrm{~h}$ of light $\left(180 \mu \mathrm{mol} \mathrm{m}^{-2} \mathrm{~s}^{-1}\right)$ at $18 \pm 2{ }^{\circ} \mathrm{C}$ and $60 \%$ humidity.

Pathogen culture

Phytophthora infestans race 1.3.4.7.10.11 (MP 946) as a virulent isolate of the pathogen was kindly supplied by 
the Plant Breeding and Acclimatization Institute (IHAR), Research Division at Młochów, Poland. Phytophthora infestans was grown on a cereal-potato medium with an addition of dextrose. A zoospore suspension of $P$. infestans was prepared exactly as described by Floryszak-Wieczorek (2000).

Plant challenge inoculation with $P$. infestans

Each potato plant was challenge-inoculated by spraying leaves with $5 \mathrm{ml}$ of a $P$. infestans zoospore suspension at a zoospore concentration of $2.0 \times 10^{5}$ per $\mathrm{ml}$ of water. For disease assessment inoculated plants were first kept for $12 \mathrm{~h}$ at $100 \%$ humidity in the dark at $18{ }^{\circ} \mathrm{C}$. Next plants were moved to a growth chamber under controlled conditions.

\section{Assessment of disease index}

The index of disease development on potato leaves at 24 , $48,72 \mathrm{~h}$ after $P$. infestans inoculation (hpi) represented the percentage of leaf area covered by late blight symptoms. Values are means of the average disease index from leaves of Al-treated and then challenge-inoculated plants from three independent experiments.

\section{NO detection by CLSM}

Nitric oxide formation was detected using a fluorescent dye $\mathrm{Cu}-\mathrm{FL}$ according to Lim et al. (2006). Copper-complex of FL (2-\{2-chloro-6-hydroxy-5-[2-methylquinolin8-ylamino)methyl]-3-oxo-3H-xanthen-9-1\}benzoic acid) was prepared as $1 \mathrm{mM}$ water stock solution according to manufacturer's instructions (Strem Chemicals, Newburyport, MA, USA). Leaf and root sections were incubated for $30 \mathrm{~min}$ at room temperature with $\mathrm{Cu}-\mathrm{FL}$ at a final concentration of $10 \mu \mathrm{M}$ in $10 \mathrm{mM}$ Tris- $\mathrm{HCl}$ buffer, $\mathrm{pH}$ 7.2. The incubation solution was then removed and sections were studied under an epifluorescence microscope (Axiostar plus, Zeiss) equipped with an AxioCam MRc 5 camera (Zeiss). For observation of NO-FL fluorescence the Filter Set 16 (Zeiss) (ex. 485/20; em. 515 nm) were used. Fluorescence intensity in extracts was determined at Fluorescence Spectrometer Perkin Elmer LS 50B (UK) using 488 and $516 \mathrm{~nm}$ for excitation and emission, respectively.

\section{Measurement of SA}

Salicylic acid in free form (SA), as well as that conjugated as a glucoside ( $\mathrm{SAG}$ ), were determined according to the methodology recommended by Yalpani et al. (1993). Plant tissues were ground in liquid nitrogen to a fine powder from which approximately $0.5 \mathrm{~g}$ was taken for analysis. Salicylic acid was extracted twice with methanol. After centrifugation, the supernatant was divided into two equal parts and the solvent was evaporated to dryness under a stream of nitrogen. A $5 \%$ solution of trichloroacetic acid was added to one part and then SA was extracted three times into ethyl acetate:cyclopentane:isopropanol (100:99:1, by vol.). To determine the total (free and glucoside bound) salicylic acid (TSA), 40 units of $\beta$-glucosidase (Sigma) in acetate buffer $(0.1 \mathrm{M}, \mathrm{pH} 5.2)$ were added to the second part of the dry extract and incubated for $90 \mathrm{~min}$ at $37^{\circ} \mathrm{C}$. The reaction was terminated by the addition of $5 \%$ trichloroacetic acid and then salicylic acid was extracted as described above. After solvent evaporation, the dry residue was dissolved in a mobile phase $(0.2 \mathrm{M}$ acetate buffer, $\mathrm{pH} 5.0 ; 0.5 \mathrm{mM}$ EDTA) and analyzed by the HPLC method coupled with fluorometric detection with a Waters chromatograph composed of 2,699 Separation Module Alliance and 2,475 Multi- $\lambda$ Fluorescence Detector (Waters Corp., Milford, MA, USA). Chromatographic separation was performed on a Spherisorb ODS2 Waters column $(3 \mu \mathrm{m}, 4.6 \times 10 \mathrm{~mm})$ (Waters Corp., Wexford, Ireland). Detection parameters were as follows: $295 \mathrm{~nm}$ for excitation and $405 \mathrm{~nm}$ for emission. The content of the salicylic acid released from its glucoside was calculated as the difference between assays without and with glucoside enzymatic degradation $(\mathrm{SAG}=\mathrm{TSA}-\mathrm{SA})$. The relationship between the peak area and the concentration of salicylic acid was found to be highly linear with a regression coefficient $R^{2}>0.9999$. The recovery of the standard added to samples amounted to 89 and $86 \%$ for SA and TSA assays, respectively.

\section{Measurement of $\mathrm{H}_{2} \mathrm{O}_{2}$}

$\mathrm{H}_{2} \mathrm{O}_{2}$ concentration was assayed spectrophotometrically using the titanium $\left(\mathrm{Ti}^{4+}\right)$ method described by Becana et al. (1986). Leaves, stems and roots $(0.25 \mathrm{~g})$ were homogenized in $3 \mathrm{ml}$ of $0.1 \mathrm{M}$ potassium phosphate buffer $(\mathrm{pH}$ 7.8). After centrifugation $(15,000 \mathrm{~g}$ for $30 \mathrm{~min})$, the supernatant was used for further assays. The reaction mixture $(1.5 \mathrm{ml})$ contained $0.1 \mathrm{M}$ potassium phosphate buffer $(\mathrm{pH}$ 7.8), enzymatic extract $(400 \mu 1)$ and titanium reagent. Titanium reagent was prepared on the day of assay by mixing $0.6 \mathrm{mM}$ solution of 4-(2-pyridylazo) resorcinol and $0.6 \mathrm{mM}$ potassium titanium tartrate at a 1:1 ratio. The prepared solution was kept in an ice bath. The concentration of $\mathrm{H}_{2} \mathrm{O}_{2}$ was estimated by measuring absorbance at a wavelength of $508 \mathrm{~nm}$ against a calibration curve and expressed as mmol $\mathrm{H}_{2} \mathrm{O}_{2}$ per $1 \mathrm{~g}$ fresh weight ( $\mathrm{FW}$ ).

GSNOR activity (EC 1.2.1.46)

The GSNOR activity was determined according to the procedure proposed by Barroso et al. (2006) with minor 
modifications. All operations were carried out at $0-4{ }^{\circ} \mathrm{C}$. Fresh leaves, stems and roots $(0.5 \mathrm{~g})$ were homogenized in $0.1 \mathrm{M}$ Tris-HCl buffer, $\mathrm{pH} 7.5(1: 4 \mathrm{w} / \mathrm{v})$ containing $0.2 \%$ Triton X-100 (v/v), $10 \%$ glycerol (v/v), $0.1 \mathrm{mM}$ EDTA, $2 \mathrm{mM}$ DTT and centrifuged at 27,000 $\mathrm{g}$ for $25 \mathrm{~min}$. Supernatants were passed through Sephadex G-25 gel filtration columns (Illustra NAP-10 from GE Healthcare), then immediately through Amicon Ultra 3K Filters (Millipore) and served as the enzyme extract. The $1 \mathrm{ml}$ volume of the assay reaction mixture contained $0.5 \mathrm{mM}$ EDTA, $0.2 \mathrm{mM}$ NADH, $0.4 \mathrm{mM}$ GSNO and $30 \mu 1$ enzyme extract in $25 \mathrm{mM}$ Tris- $\mathrm{HCl}$ buffer, $\mathrm{pH}$ 8.0. The reaction was run at $25{ }^{\circ} \mathrm{C}$ and initiated with an addition of GSNO (Sigma Aldrich). NADH oxidation was determined at $340 \mathrm{~nm}$ and rates of NADH consumed at $\mathrm{min}^{-1}$ were calculated using an extinction coefficient of $6,220 \mathrm{M}^{-1} \mathrm{~cm}^{-1}$.

\section{$\beta$-1,3-Glucanase activity (EC 3.2.1.6)}

The $\beta$-1,3-glucanse activity was determined according to the procedure proposed by Abeles and Forrence (1970) in a colorimetric assay utilizing laminarin as a substrate. All operations were carried out at $0-4{ }^{\circ} \mathrm{C}$. Fresh leaves and roots $(0.25 \mathrm{~g})$ were homogenized in $0.05 \mathrm{M}$ potassiumacetate buffer, $\mathrm{pH} 5.0(1: 16 ; \mathrm{w} / \mathrm{v})$, containing $0.125 \mathrm{~g}$ Polyclar AT and then centrifuged at $15,000 \mathrm{~g}$ for $25 \mathrm{~min}$. Supernatants $(0.5 \mathrm{ml})$ were added to $0.5 \mathrm{ml} 2 \%(\mathrm{w} / \mathrm{v})$ laminarin aqueous solution and incubated for $2 \mathrm{~h}$ at $50{ }^{\circ} \mathrm{C}$. The reaction was stopped by adding $3 \mathrm{ml}$ of the dinitrosalicylic reagent and probes were heated for $5 \mathrm{~min}$ at $100{ }^{\circ} \mathrm{C}$. The probes were then cooled to $25^{\circ} \mathrm{C}$, the contents were diluted with water to $1: 10$ and the optical density was read at $500 \mathrm{~nm}$. The $\beta-1,3$-glucanase activity was determined as a level of reducing sugars produced and served as glucose equivalents in $\mu$ mol glucose $\mathrm{mg}^{-1}$ protein $\min ^{-1}$.

Chitinase activity (EC 3.2.1.14)

Chitinase activity was determined according to Derckel et al. (1996) with some modifications. Fresh leaves and roots $(0.25 \mathrm{~g})$ were homogenized in $50 \mathrm{mM}$ sodium buffer, pH $5.0(1: 10 ; w / v)$ containing 0.125 g Polyclar AT and then centrifuged at $15,000 \mathrm{~g}$ for $25 \mathrm{~min}$. The diluted (1:10) enzyme extract $(0.2 \mathrm{ml})$ was incubated at $25^{\circ} \mathrm{C}$ in an Eppendorf microcentrifuge tube with $0.2 \mathrm{ml}$ of CM-Chitin-RBV (Loewe Biochemica, Germany) and $0.4 \mathrm{ml}$ of $50 \mathrm{mM}$ sodium acetate buffer $\mathrm{pH} 5.0$ for $60 \mathrm{~min}$. Next the reaction was stopped by the addition of $0.2 \mathrm{ml} 2 \mathrm{M} \mathrm{HCl}$ and cooled on ice for $10 \mathrm{~min}$. After the centrifugation at $10,000 \mathrm{~g}$ for $5 \mathrm{~min}$, the mixture was transferred to a plastic cuvette and absorbance was measured at $550 \mathrm{~nm}$. Chitinase activity was expressed as units per mg protein, with one unit equal to $1 \mu \mathrm{g}$ CM-chitinRBV hydrolyzed per minute ( $\mu \mathrm{g}$ CM-chitin-RBV/min).
Quantification of total SNOs

Total SNO content was determined by chemiluminescence using a Sievers ${ }^{\circledR}$ Nitric Oxide Analyzer NOA 280i (GE Analytical Instruments, Boulder, CO, USA) according to the procedure proposed by Valderrama et al. (2007) with minor modifications. The detection of SNOs depends on the reductive decomposition of nitroso compounds by an iodine/triiodide mixture in the presence of copper. Gaseous NO released from the mercury-induced decomposition of SNOs is measured by gas-phase chemiluminescence at the PMT device. Fresh leaves, stems and roots $(0.5 \mathrm{~g})$ were homogenized in Tris-HCl $0.1 \mathrm{M}$ buffer $\mathrm{pH} 7.5$ (1:4, w/v) containing $100 \mu \mathrm{M}$ DTPA, $1 \mathrm{mM}$ EDTA, $1 \mathrm{mM}$ EGTA, $1 \mathrm{mM}$ PMSF, $0.1 \mathrm{mM}$ neocuproine, $3.5 \%$ (w/v) PVPP, $0.25 \%(\mathrm{v} / \mathrm{v})$ Triton X-100 and centrifuged at 3,000g for $10 \mathrm{~min}$. The supernatants were incubated with $10 \mathrm{mM}$ NEM ( $N$-ethylmaleimide) for $15 \mathrm{~min}$ at $4{ }^{\circ} \mathrm{C}$ and subsequently two aliquots were prepared for each sample. To remove nitrite one aliquot was incubated for $15 \mathrm{~min}$ with $10 \mathrm{mM}$ sulphanilamide at $4{ }^{\circ} \mathrm{C}$. To eliminate nitrite and decompose SNOs the next aliquot was treated with $10 \mathrm{mM}$ sulphanilamide and $7.3 \mathrm{mM} \mathrm{HgCl}$ for $15 \mathrm{~min}$ at $4{ }^{\circ} \mathrm{C}$. The difference between detected signals obtained from these aliquots demonstrated the total SNO content. Due to SNO sensitivity to light the whole procedure was performed under a red safety light.

\section{Immunohistochemical studies of SNOs}

Detection of SNOs by fluorescence microscopy using the fluorescent Alexa Fluor $405 \mathrm{Hg}$-Link reagent phenylmercury was performed according to Corpas et al. (2008) with some modifications. Potato root and leaf segments were incubated at $25{ }^{\circ} \mathrm{C}$ for $1 \mathrm{~h}$ in darkness with $10 \mathrm{mM}$ NEM prepared in ethanol, and then were washed three times in $10 \mathrm{mM}$ Tris- $\mathrm{HCl}$ buffer, $\mathrm{pH}$ 7.4, for $15 \mathrm{~min}$ each. Then they were incubated in the dark with $10 \mu \mathrm{M}$ Alexa Fluor $405 \mathrm{Hg}$-link phenylmercury (Molecular Probes, USA) for $1 \mathrm{~h}$ at $25{ }^{\circ} \mathrm{C}$. After being washed three times in $10 \mathrm{mM}$ Tris- $\mathrm{HCl}$ buffer the sections were analyzed with an epifluorescence microscope (Axiostar plus, Zeiss) equipped with an AxioCam MRc 5 camera (Zeiss) using standard filters for Alexa Fluor 405 blue fluorescence (excitation $401 \mathrm{~nm}$; emission $421 \mathrm{~nm}$ ). For background staining control sections were incubated with $\beta$-mercaptoethanol plus Alexa Fluor 405 and without NEM.

\section{Gene expression measurement}

The RNA was isolated from $200 \mathrm{mg}$ of frozen leaf and root tissues using TriReagent (Sigma). The obtained RNA was 
purified with the use of a Deoxyribonuclease Kit (Sigma). For the reverse transcription $1 \mu l$ of RNA from every experimental variant was processed with a Reverse Transcription Kit (Thermo Scientific Fermentas) according to the manufacturer's instructions. Real-time PCR was performed on a RotorGene 6000 Thermocycler. The reaction mixture contained $0.1 \mu \mathrm{M}$ of each primer, $1 \mu \mathrm{l}$ of $5 \times$ diluted cDNA, $10 \mu \mathrm{l}$ of the Power SYBR Green PCR Master mix (Applied Biosystems) and DEPC treated water to the total volume of $20 \mu \mathrm{l}$. The real-time PCR reaction conditions included an initial 5-min denaturation at $95{ }^{\circ} \mathrm{C}$, followed by 55 cycles consisting of $10 \mathrm{~s}$ at $95{ }^{\circ} \mathrm{C}, 20 \mathrm{~s}$ at $55^{\circ} \mathrm{C}$ and $30 \mathrm{~s}$ at $72{ }^{\circ} \mathrm{C}$. The reaction was finalized by denaturation at a temperature rising from 72 to $95{ }^{\circ} \mathrm{C}$ by one degree at every $5 \mathrm{~s}$. Reaction specificity was confirmed by the occurrence of one peak in the melting curve analysis. The data were normalized to two reference genes encoding elongation factor (ef1 $\alpha$, AB061263) and 18S RNA (X67238). All used primers are presented in Suppl. Table S1. The Ct values were
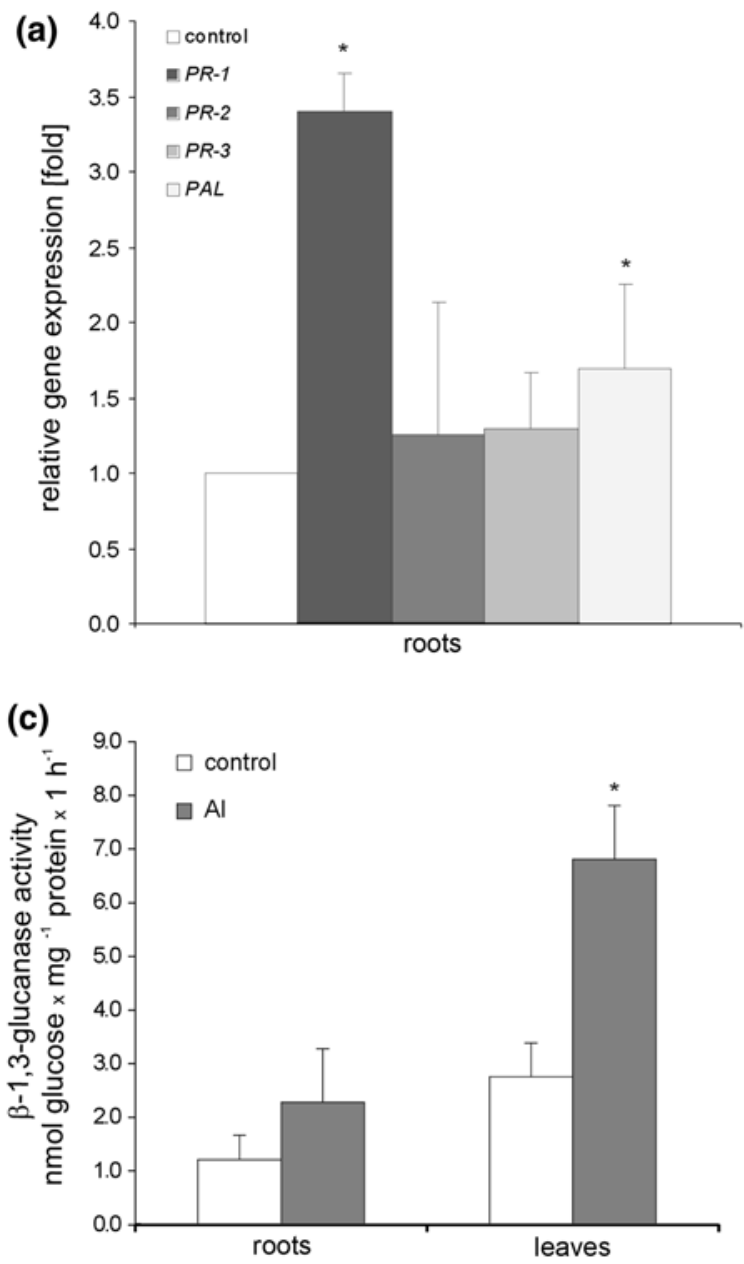

Fig. 1 The qRT-PCR analysis of $P R-1, P R-2, P R-3$ and $P A L$ gene expression in roots (a) and leaves (b) of potato exposed to $250 \mu \mathrm{M}$ $\mathrm{AlCl} 3$ at $48 \mathrm{~h}$. $\beta-1,3-$-Glucanase (c) and chitinase (d) activities in roots determined with the use of a Real-time PCR Miner (Zhao and Fernald 2005) and the relative gene expression was calculated with the use of efficiency corrected calculation models presented in Pfaffl (2004).

\section{Protein concentration}

Protein concentration was assayed according to Bradford (1976) using bovine serum albumin as a standard.

\section{Statistical analysis}

All experiments included three independent experiments carried out in at least three technical replications. For each experiment means of the obtained values were calculated along with standard deviations. The analysis of variance was performed and the least significant differences (LSDs) between means were determined using Tukey's test at the level of significance $\alpha=0.05$.
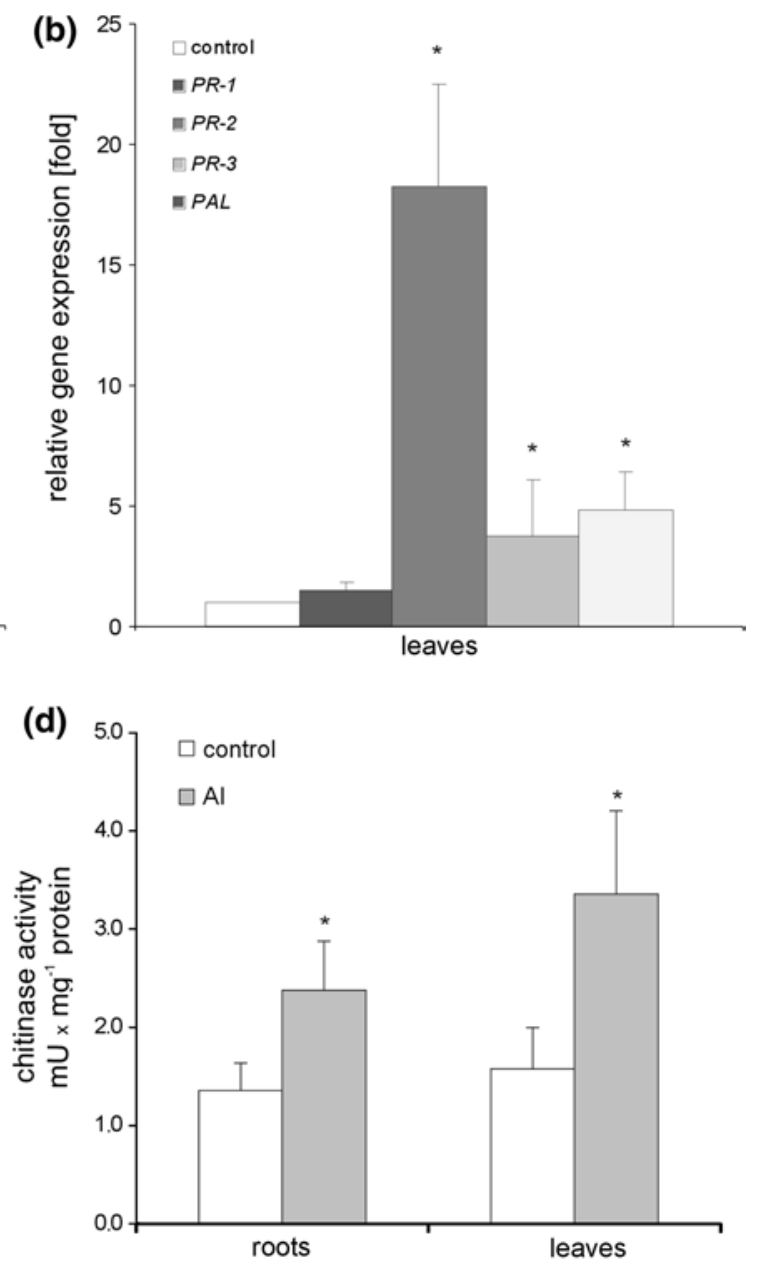

and leaves of Al-treated potato. Asterisks indicate values that differ significantly from the non-treated (control) potato plants at $P<0.05$, $n=3$ 
Fig. 2 The level of free SA and SA conjugated with Glc in potato plants exposed to $250 \mu \mathrm{M} \mathrm{AlCl} 3$ at $48 \mathrm{~h}$. SA and SAG content was measured in roots (a), shoots (b) and leaves (c). Asterisks indicate values that differ significantly from the non-treated control plants at $P<0.05$
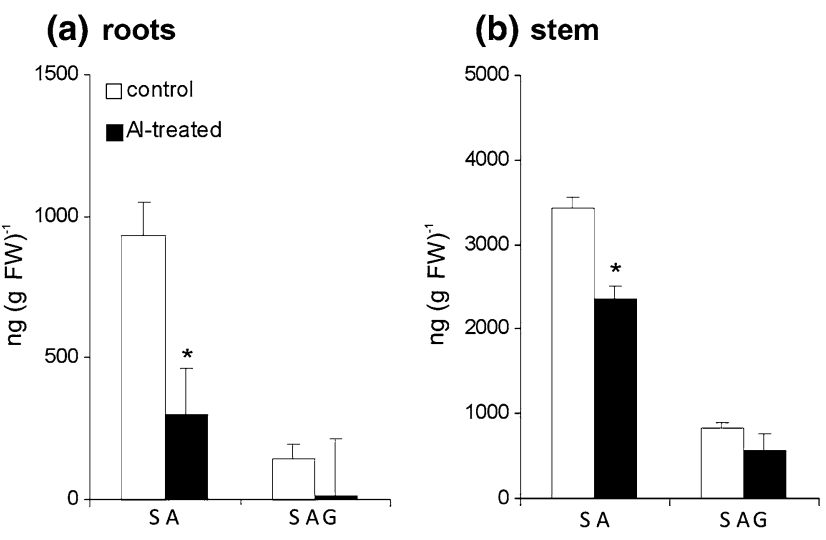

\section{Results}

Aluminum exposure activated key markers of plant defense responses in both roots and leaves

Potato exposure to $\mathrm{Al}$ significantly up-regulated the expression of two of the four studied defense-related genes in roots including $P R-1$ and $P A L$. However, the highest expression level (over threefold increase) was noted for $P R-1$ (Fig. 1a). In leaves mRNA coding for $P R-2, P R-3$ and $P A L$ was effectively increased, ranging from 3 - to 18 -fold increase for $P R-3$ and $P R-2$, respectively (Fig. 1b). A distinct pattern of expression was observed for $P R-1$, since $\mathrm{Al}$ did not elicit the significant rise of PR-1 transcript accumulation in distal organs. Furthermore, Al-mediated upregulation of $P R-2$ and $P R-3$ in leaves was correlated in time with an elevated $\beta-1,3$-glucanse and chitinase activity (Fig. 1c, d).

It worth pointing that the used $\mathrm{Al}$ concentration $(250 \mu \mathrm{M}$ $\mathrm{AlCl}_{3}$ ) includes in the tolerance limit noted for potato plants, since inhibition of root growth by $50 \%$, known as the tolerance index, was observed at $\mathrm{Al}$ concentration of $500 \mu \mathrm{M}$ (see Supporting Information Fig. S1).

Aluminum triggered distal signaling in potato plants

To determine if root exposure to $\mathrm{Al}$ may modulate a poststress signaling network in the upper organs, the levels of $\mathrm{SA}, \mathrm{NO}$ and $\mathrm{H}_{2} \mathrm{O}_{2}$ in stems and leaves were also determined. The relatively short-term exposure of potato plants to $\mathrm{Al}$ provoked a marked, by ca. $70 \%$, decrease in free SA content in roots (Fig. 2a). The abated level of SA accumulation in response to $\mathrm{Al}$ treatment was observed in potato stems as well; however, the steady-state level of free SA was higher than in roots (Fig. 2b). Surprisingly, the level of free $\mathrm{SA}$ in leaves increased by over threefold in response to $\mathrm{Al}$ treatment (Fig. 2c).

The production of salicylic acid beta-glucoside (SAG) was also reduced in response to $\mathrm{Al}$ treatment in both roots
Fig. 3 Bio-imaging of $\mathrm{NO}$ with a $\mathrm{Cu}-\mathrm{FL}$ fluorescent probe in potato roots $(\mathbf{a}-\mathbf{c})$ and leaves $(\mathbf{d}, \mathbf{e}, \mathbf{g}-\mathbf{i})$ at $48 \mathrm{~h}$ after root exposure to $250 \mu \mathrm{M} \mathrm{AlCl}_{3}$. Images show general phenomena representative of three individual experiments; control of background where the fluorescent probe was omitted (f). Bars indicate $200 \mu \mathrm{m}(\mathbf{d}-\mathbf{f}), 100 \mu \mathrm{m}$ $(\mathbf{a}, \mathbf{c}, \mathbf{g}, \mathbf{h})$ and $20 \mu \mathrm{m}(\mathbf{b}, \mathbf{i})$. Measurement of FL-NO fluorescence in extracts of potato roots $(\mathbf{j})$, stems $(\mathbf{k})$ and leaves (l) exposed to aluminum. NO production was assayed spectrofluorimetrically using a selective NO sensor (Cu-FL). FL-NO fluorescence intensity represents mean values for the average of data $\pm \mathrm{SD}$ of three independent experiments

and stems (Fig. 2a, b). In turn, the content of the storage form of the analyzed signal in leaves was over three times higher in comparison to non-treated plants (Fig. 2c).

The localization of NO was analyzed by fluorescence microscopy using the selective fluorescent probe cuppercomplex (Cu-FL), where green fluorescence corresponds to the location of NO. Based on FL-NO fluorescence we observed that the control potato generated considerable amounts of NO only in the root apical zone (Fig. 3a, b). The treatment with $250 \mu \mathrm{M} \mathrm{AlCl}_{3}$ for $48 \mathrm{~h}$ significantly diminished NO synthesis in the elongation and differentiation zone of potato roots (Fig. 3c). In addition, quantitative measurement of FL-NO fluorescence in potato extracts confirmed a decrease in NO synthesis in roots and revealed diminished the signal generation in stems as well (Fig. 3j, $\mathrm{k}$ ). In leaves NO-dependent fluorescence was increased (Fig. 3g-i, 1). The enhanced NO formation was found particularly in the parenchyma and in single cells of palisade mesophyll (Fig. 3g-i). The application of $1 \mathrm{mM}$ PTIO almost completely eliminated green fluorescence in $\mathrm{Al}-$ treated potato (see Supporting Information Fig. S2). The potato leaf cross section was presented in Supporting Information (Fig. S3).

The reduced $\mathrm{NO}$ formation in potato roots exposed to $\mathrm{Al}$ was accompanied by a statistically significant $\mathrm{H}_{2} \mathrm{O}_{2}$ accumulation (Fig. 4a). In turn, in the upper organs, i.e. stems and leaves, $\mathrm{H}_{2} \mathrm{O}_{2}$ remained at almost the same level as in the non-treated potato (Fig. $4 \mathrm{~b}, \mathrm{c}$ ). 

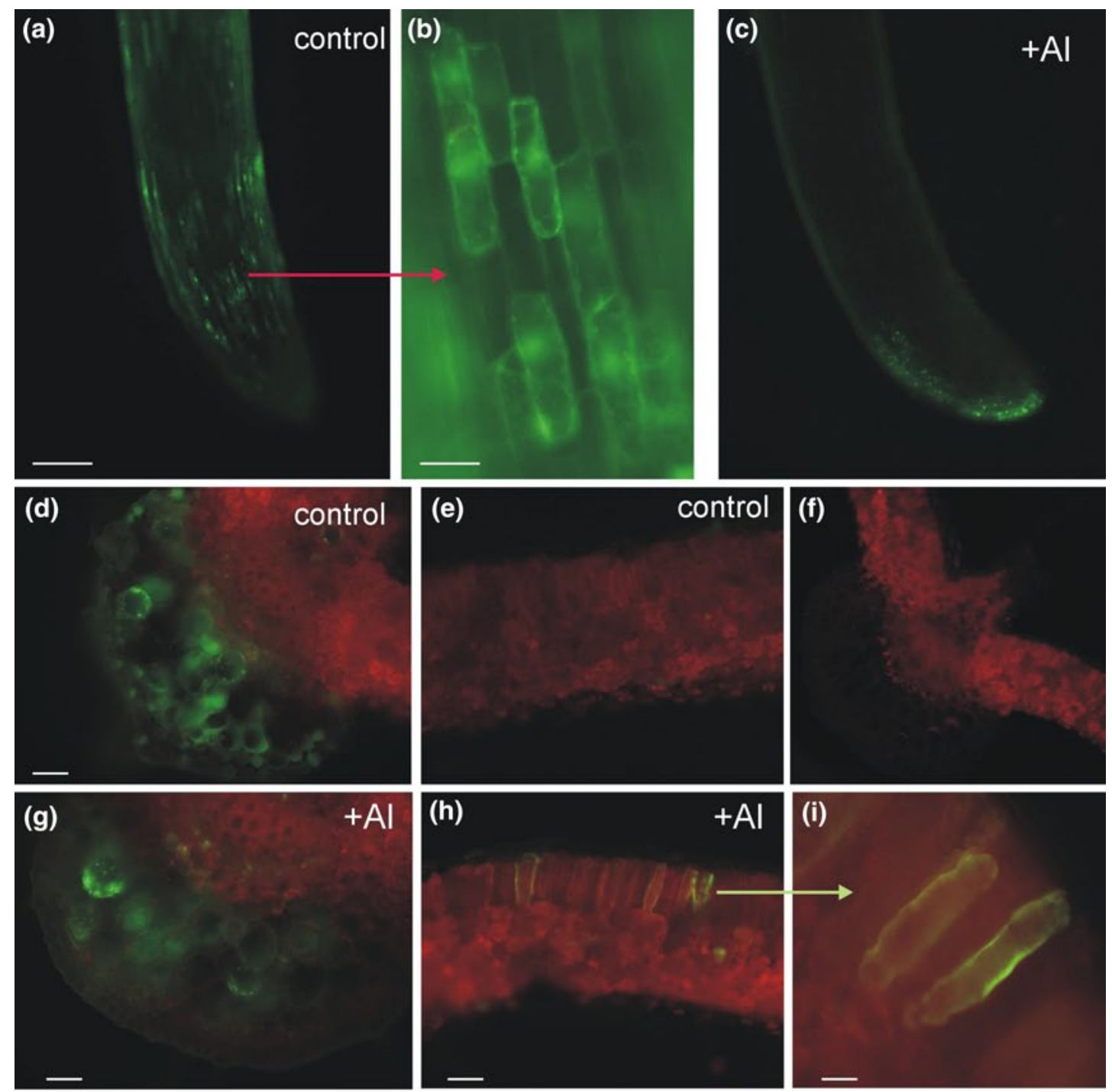

(j) roots

(k) stem

(I) leaves
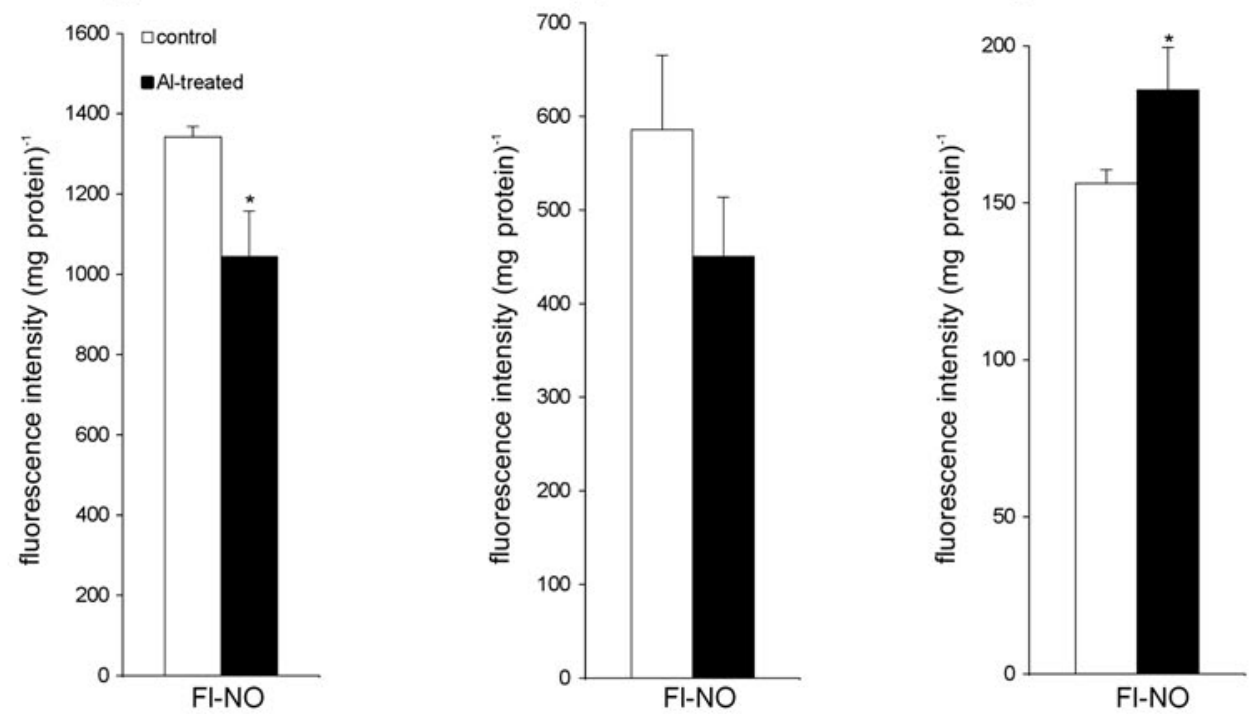
Fig. 4 The effect of aluminum stress at $48 \mathrm{~h}$, supplied as $250 \mu \mathrm{M} \mathrm{AlCl}$, on hydrogen peroxide accumulation in roots (a), stems (b) and leaves (c) of potato cv. 'Bintje'. Asterisks indicate values that differ significantly from non-treated control potato plants at $P<0.05$
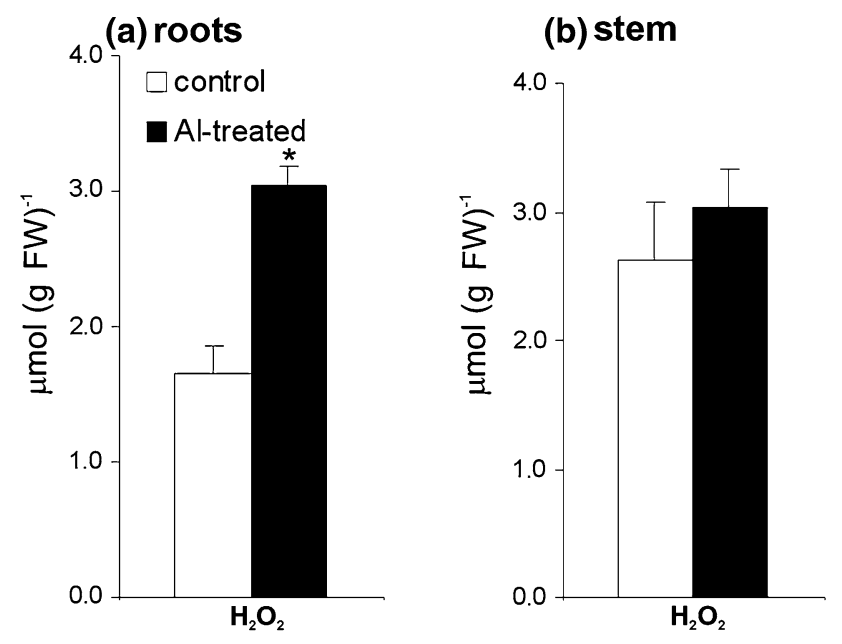

The metabolic status of NO was affected during aluminum exposure

To gain further insight into the participation of NO in the acquisition of the cross-resistance phenomenon between aluminum and biotic stress, the key parameters involving NO metabolism were analyzed. Based on a precise chemiluminescence method it was found that $\mathrm{Al}$ exposure reduced by approx. $25 \%$ the total pool of SNOs in roots, whereas twofold higher SNOs production was observed in leaves and stems (Fig. 5a-c). Additional localization of SNOs using a fluorescent probe, Alexa Fluor $405 \mathrm{Hg}$-link, in control leaves showed blue fluorescence attributable to SNOs, present mainly in the phloem tissue (Fig. 5h). In leaves of Al-supplied plants the distribution of SNOs was expanded not only in the vascular tissue, but also in the spongy and palisade mesophyll (Fig. 5g, i, j). Moreover, the treatment with $250 \mu \mathrm{M} \mathrm{AlCl}_{3}$ for $48 \mathrm{~h}$ significantly diminished SNOs formation in potato roots (Fig. 5e). When $\mathrm{N}$-ethyl maleimide (NEM) and Alexa Fluor $405 \mathrm{Hg}$-link were omitted in the incubation mixture, blue fluorescence was almost undetectable and similar results were obtained when the Alexa Fluor $405 \mathrm{Hg}$-link was added and NEM omitted (data not presented).

The results suggest that cellular SNOs (mainly GSNO) homeostasis is controlled by GSNO reductase (Liu et al. 2001). In continuation of this experimental investigation our data showed that $\mathrm{Al}$ caused GSNOR activity up-regulation by approx. 20 and $45 \%$ in leaves and stems, respectively (Fig. 6b, c). The enzyme activity in roots was comparable to the non-treated control (Fig. 6a).

Aluminum exposure diminished late blight disease development on potato leaves

To assess the existence of a cross-resistance phenomenon between $\mathrm{Al}$ and $P$. infestans, potato plants were pretreated for $48 \mathrm{~h}$ with the metal at the root level and next inoculated with the oomycete pathogen at the leaf level. Based on the index of disease assay it was found that the metal effectively reduced symptoms of late blight disease. Pre-exposure to $\mathrm{Al}$ and a subsequent challenge inoculation showed disease limitation, resulting in approx. 20-30\% reduction of disease symptoms at 2 nd and 3 rd day after $P$. infestans treatment, respectively (Fig. 7).

Aluminum enhanced molecular fingerprint accumulations of plant resistance in leaves after challenge inoculation with $P$. infestans

The reduced disease symptoms observed after inoculation with $P$. infestans were correlated with an enhanced defense response in leaves. To highlight the effect of $\mathrm{Al}$ pretreatment during pathogen infestation we used non-treated (acid control), $P$. infestans inoculated leaves as a control to Al-treated, $P$. infestans inoculated leaves. The quantitative RT-PCR data revealed that Al-exposed, subsequently challenge-inoculated potato leaves showed a strong induction of genes encoding $P R s$ and $P A L$. The expression of all studied defense-related genes was effectively up-regulated in response to pathogen challenge starting from $24 \mathrm{hpi}$ (Fig. 8). The highest amount of mRNA (over 35-fold increase) coding for $P R s$ was noted for $P R-1$. At the late stage of disease development, i.e. at $72 \mathrm{hpi}$, an enhanced expression was still noted for $P A L$ gene (Fig. 8). The use of Al-treated, mock inoculated leaves as a control was presented in Supporting Information Fig. S4.

\section{Discussion}

A wealth of evidence demonstrates that a high concentration of aluminum disturbs crucial physiological processes in plants, resulting in a variety of toxicity symptoms 


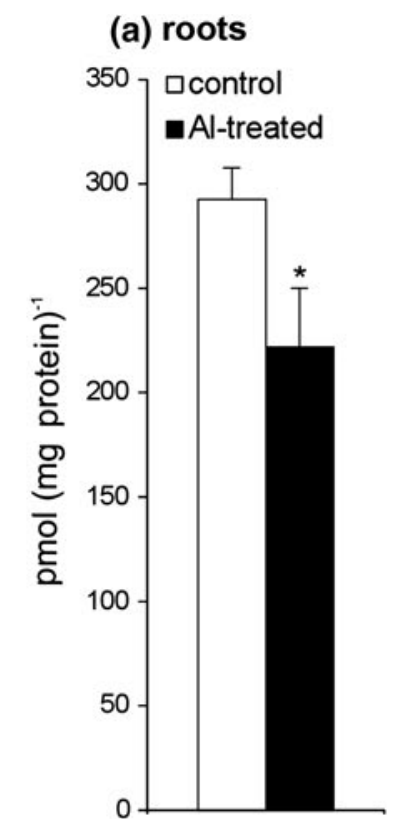

(b) stem

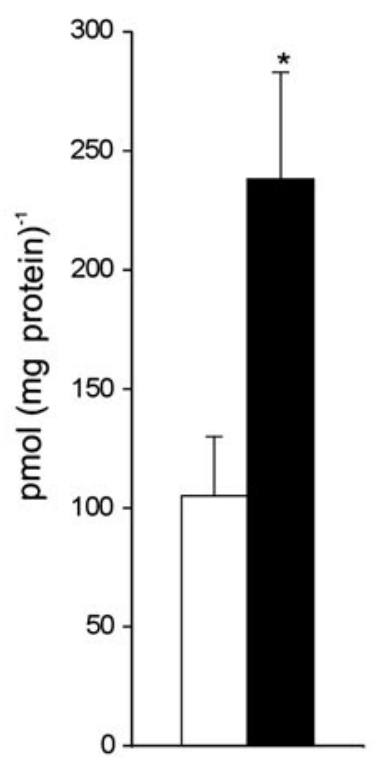

(c) leaves

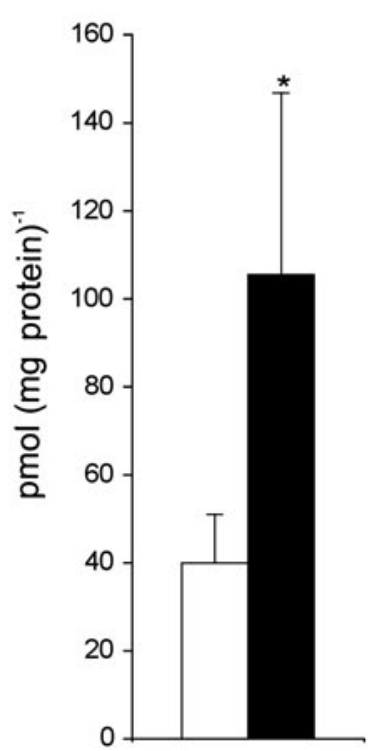

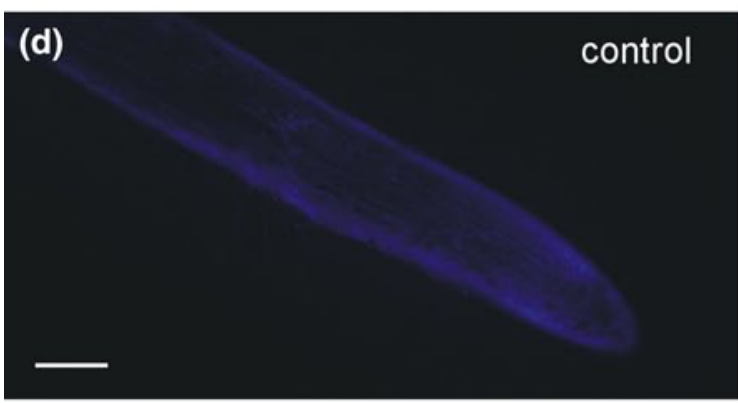
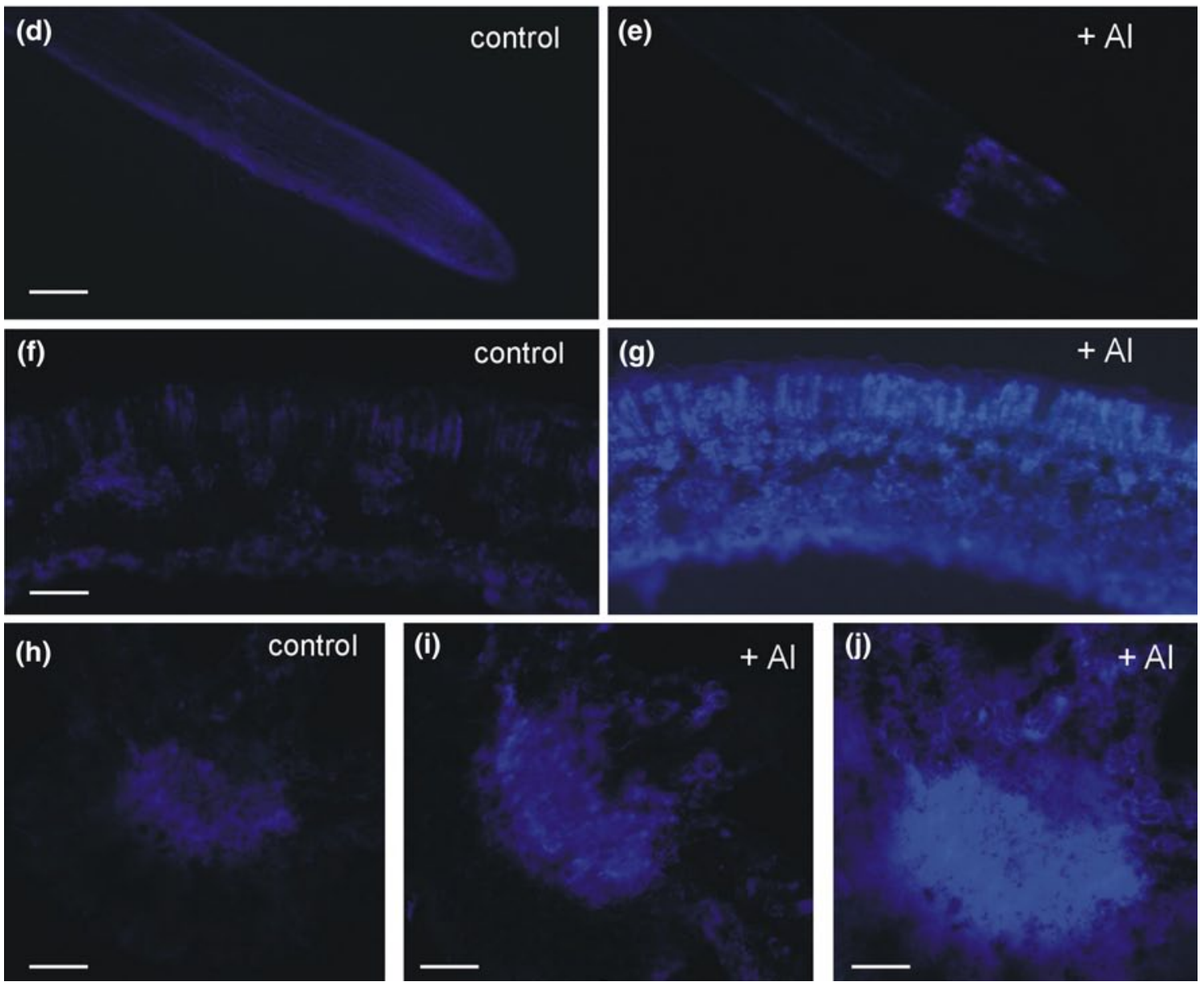

Fig. 5 Total contents of $S$-nitrosothiols (SNOs) in roots (a), stems (b) and leaves (c) of potato cv. 'Bintje' treated with $250 \mu \mathrm{M} \mathrm{AlCl}_{3}$ or without $\mathrm{AlCl}_{3}$ (acidic control) at $48 \mathrm{~h}$. Nitrosothiol content was determined by chemiluminescence using a Sievers ${ }^{\circledR}$ Nitric Oxide Analyzer NOA 280i. Detection of SNOs in potato leaves by immunofluores- cence histochemistry using Alexa Fluor $405 \mathrm{Hg}$-Link reagent phenylmercury. Blue fluorescence attributable to SNOs in roots $(\mathbf{d}, \mathbf{e})$ and leaves $(\mathbf{f}-\mathbf{j})$ of control and Al-treated potato. Bars indicate $250 \mu \mathrm{m}$ $(\mathbf{d}, \mathbf{e}), 200 \mu \mathrm{m}(\mathbf{h}, \mathbf{i}), 100 \mu \mathrm{m}(\mathbf{f}, \mathbf{g}, \mathbf{j})$. Asterisks indicate values that differ significantly from non-treated control potato plants at $P<0.05$ 
Fig. 6 The effect of aluminum stress at $48 \mathrm{~h}$, supplied as $250 \mu \mathrm{M} \mathrm{AlCl}_{3}$, on GSNO reductase activity in roots (a), stems (b) and leaves (c) of potato cv. 'Bintje'. Asterisks indicate values that differ significantly from non-treated control potato plants at $P<0.05$ (a) root

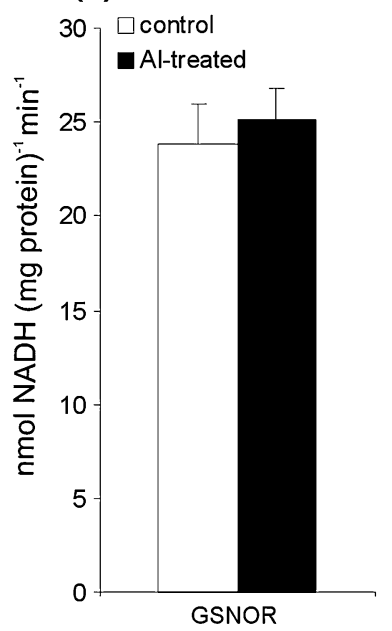

(b) stem

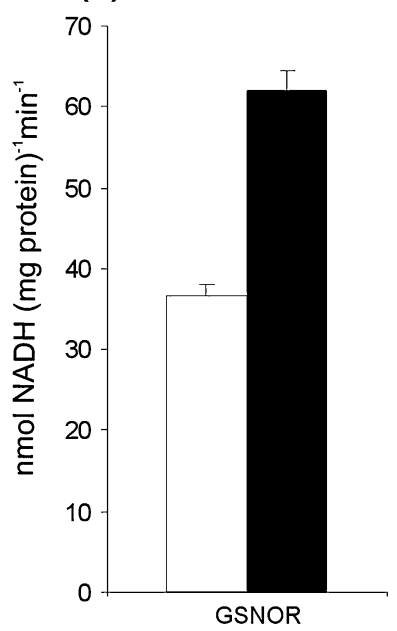

(c) leave

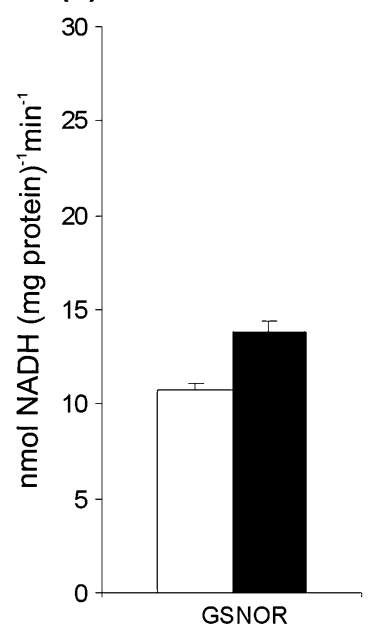

ranging from root growth inhibition to leaf chlorosis and necrosis. In turn, a general feature of active defense responses to this metal in plants depending on the Al dose might be executed by the stimulation of intracellular signaling pathways, leading to the expression of target genes, resulting in de novo synthesis of specific proteins engaged in plant protective or destructive metabolic changes.

\section{Aluminum triggered key hallmarks of plant defense in potato}

In the present study, a short-term Al treatment of potato plants activated key markers of plant defense against pathogens, including $P R-1$ and $P A L$ at the root level. This finding is in line with previous reports showing that a number of PR genes and proteins including PR-4 like protein, thaumatin-like proteins, $\beta$-1,3-glucanase and chitinase were upregulated in plant tissues directly exposed to $\mathrm{Al}$ (Mao et al. 2004; Chandran et al. 2008). The expression of $P R$ families upon Al supply shows similarities to another induced defense response link to oxidative stress and lipid peroxidation, which have been shown to up-regulate PR proteins (Hong and Hwang 2005). Furthermore, it is known that class 1 of PR proteins, observed by us in Al-treated potato roots, is engaged in defense with antimicrobial activity ubiquitously synthesized by host plants in response to pathogen infections (e.g. Van Loon and Van Strien 1999) as well as by developmental signals (Lotan et al. 1989).

It was found in our study that in contrast to potato roots Al was unable to induce the expression of the $P R-1$ gene at the distal leaf level. Our data revealed that in potato systemic leaves only $P R-2$ and $P R-3$ were effectively expressed at both mRNA and enzyme activity levels in response to root uptake of $\mathrm{Al}$. Interestingly, the $P R-2$ gene was also inducible in systemic leaves of Arabidopsis plants exposed to excess light (Mullineaux et al. 2000).
It has been reported that a pepper gene, $C A B P R 1$, which encodes the basic PR-1 protein, is induced after abiotic treatment including ethephon, wounding (Sarowar et al. 2005) and copper (Chmielowska et al. 2010). Moreover, transgenic tobacco overexpressing the pepper gene CABPR1 was found to confer resistance not only to pathogens, but also enhanced tolerance to heavy metals such as mercury and cadmium (Sarowar et al. 2005). These transgenic lines exhibited a significant decline in total peroxidase activity, suggesting that overexpression of CABPR 1 in tobacco cells altered the redox balance, triggering an $\mathrm{H}_{2} \mathrm{O}_{2}$ dependent stress tolerance cascade of metabolic changes (Sarowar et al. 2005). Although the precise role of PR proteins in combating $\mathrm{Al}$ stress is far from being resolved, the sequence of events involving local changes in the redox balance might operate also in Al-exposed potato roots.

Aluminum treatment induced local $\mathrm{H}_{2} \mathrm{O}_{2}$ accumulation

Root uptake of $\mathrm{Al}$ affected only local accumulation of $\mathrm{H}_{2} \mathrm{O}_{2}$. It is known that root cells as the first line controlling environmental factors might sense and then transfer the signals into the cell interior to trigger response in the whole plant. A local $\mathrm{H}_{2} \mathrm{O}_{2}$ over-accumulation observed in potato roots exposed to moderate and short-term Al stress was tuned with a diminished NO generation. The observed changes in the redox state in potato roots might create a cellular milieu facilitating distal signal generation.

Hydrogen peroxide senses stress signals and modulates the redox state, i.e. peroxidases, malate dehydrogenase, thiol redox-associated proteins, chitinase and PR-1a (Zhou et al. 2011). Zhou et al. (2011) identified 54 proteins regulated by $\mathrm{H}_{2} \mathrm{O}_{2}$ in apoplasts of rice roots. Remarkably, many of them are involved in carbohydrate metabolism. Thus, down-regulation of proteins involved in carbohydrate metabolism in response to $\mathrm{H}_{2} \mathrm{O}_{2}$ might be engaged 

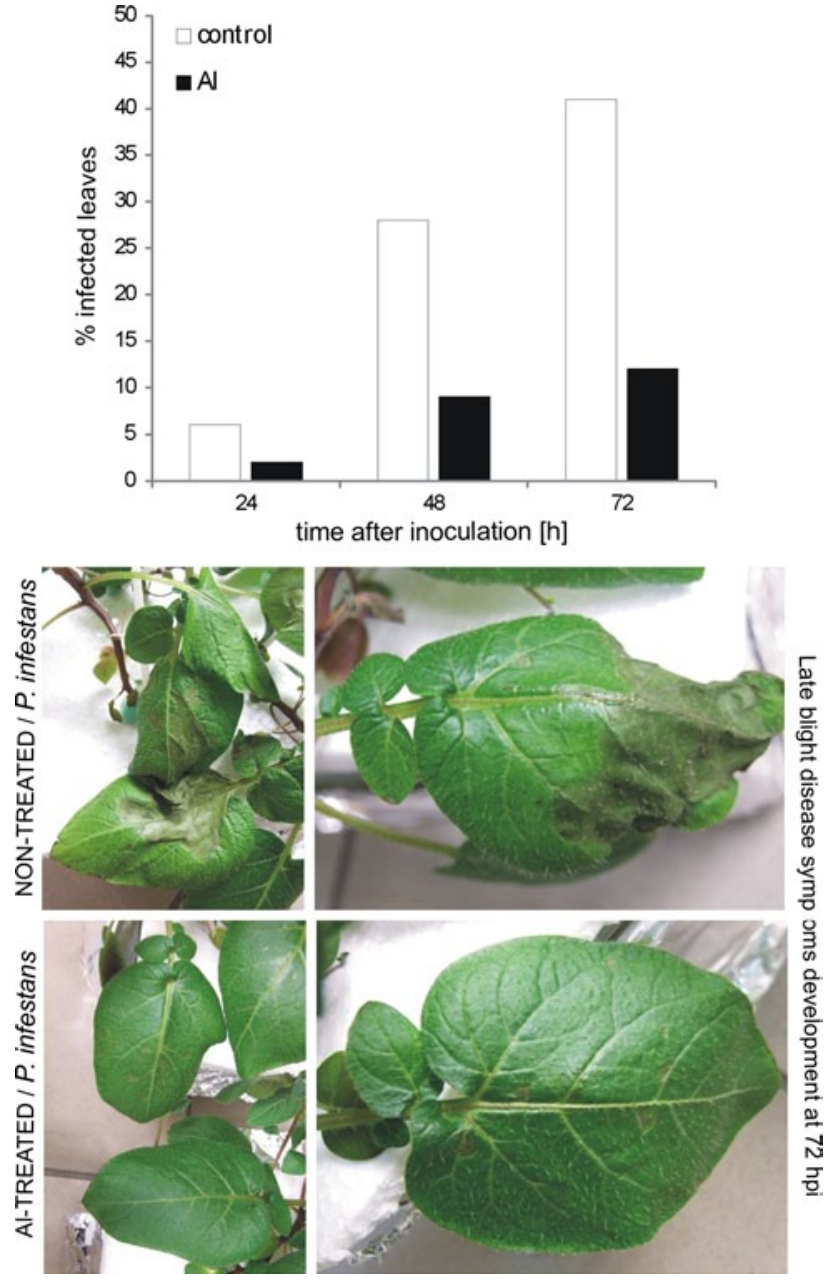

Fig. 7 Systemic protection of potato cv. 'Bintje' against $P$. infestans. Potato plants were treated at root level with water (acid control) or exposed to aluminum stress for $48 \mathrm{~h}$ and then inoculated at the leaf level. The index of disease development in potato leaves at 24, 48, $72 \mathrm{~h}$ after $P$. infestans challenge inoculation (hpi) represents the percentage of leaf area covered by late blight symptoms. Values are means of the disease index of 20 leaves from three independent experiments

in rearrangement of cell wall constituents. In turn, the $\mathrm{H}_{2} \mathrm{O}_{2}$ mediated up-regulation of UDP-glucose pyrophosphorylase, pectinesterase and $\alpha$-arabinofuranosidase probably contributes to strengthening of the cell wall by influencing polysaccharide turnover and increasing pectin demethylesterification.

Al toxicity as an important growth limiting factor of root elongation is correlated with ROS overproduction (Yamamoto et al. 2003). However, the Al-induced abundant $\mathrm{H}_{2} \mathrm{O}_{2}$ production in roots of both $\mathrm{Al}$-sensitive and Al-tolerant species has suggested that Al-dependent $\mathrm{H}_{2} \mathrm{O}_{2}$ accumulation could play a crucial role in the initiation and regulation of defense responses in roots (Xu et al. 2012). Members of different families of transcription factors, e.g. NAC, ZAT, WRKY, DREB, bZIP and MYB acting downstream of $\mathrm{H}_{2} \mathrm{O}_{2}$, are engaged in plant defense (Petrov and Van Breusegem 2012). Finally, overproduction of ROS, including $\mathrm{H}_{2} \mathrm{O}_{2}$ provoked by $\mathrm{Al}$, can also induce cell death, as it has been observed in the root tips (Panda et al. 2008).

Aluminum provoked the SA-dependent systemic pathway from roots to leaves

It is generally accepted that the essential role of SA is to activate plant defense responses and plant protection from pathogen attack (Malamy and Klessig 1992). SA-mediated signal transduction seems to be implicated in plant response to $\mathrm{Al}$ as well (Yang et al. 2003; Liu et al. 2012). SA might mediate Al-induced oxidative stress in addition to the major role of $\mathrm{SA}$ in regulation of $\mathrm{Al}$ responsive citrate efflux in plant roots by modulating aconitase and/or citrate transporters (Yang et al. 2003; Liu et al. 2012). In this study, we demonstrated for the first time a systemic activation of $\mathrm{Al}$ stress responses, since a relatively short Al treatment strongly induced free SA and its conjugated form-SAG accumulation not directly in roots exposed to the metal, but in systemic leaves. Thus, both SA and SAG levels significantly decreased in potato roots with a concomitant enhancement of $\mathrm{H}_{2} \mathrm{O}_{2}$ accumulation. It is tempting to speculate that upon exposure of potato root to $\mathrm{Al}$, SA might be bound to catalase, becoming a form of inactivation and it would lead to a local $\mathrm{H}_{2} \mathrm{O}_{2}$ accumulation that in turn could facilitate systemic signaling. Up to date, the relation between CAT activity and SA has been well defined only in biotic stress (van Breusegem et al. 2001). Moreover, $\mathrm{H}_{2} \mathrm{O}_{2}$ and SA-mediated defense signaling partly overlap, since the SA positive feedback loop is essential for amplifying distal signal for resistance or tolerance in the upper zone of the plant (ArasimowiczJelonek et al. 2012).

Aluminum modulated not only SA signaling in the upper organs of potato, but also post-stress NO generation. It was suggested earlier that $\mathrm{NO}$ might be engaged in root signaling in plants exposed to $\mathrm{Al}$ (Tian et al. 2007). A study on the internalization of aluminum into root cells revealed an inhibition of NO production in the distal portion of the transition zone in Arabidopsis roots (Illes et al. 2006). However, our new finding is that $\mathrm{Al}$ exposure provoked root-to-leaf NO signaling, since NO-FL fluorescence revealed a diminished NO synthesis in roots and stems with a concomitant enhancement of NO generation in the vascular and surrounding parenchymal cells of potato leaves. In this way $\mathrm{Al}$-induced $\mathrm{NO}$ production occurring only in distal, untreated parts of the plant could be associated with an augmented capacity for the rapid activation of defense responses after a subsequent stress event, e.g. a pathogen 

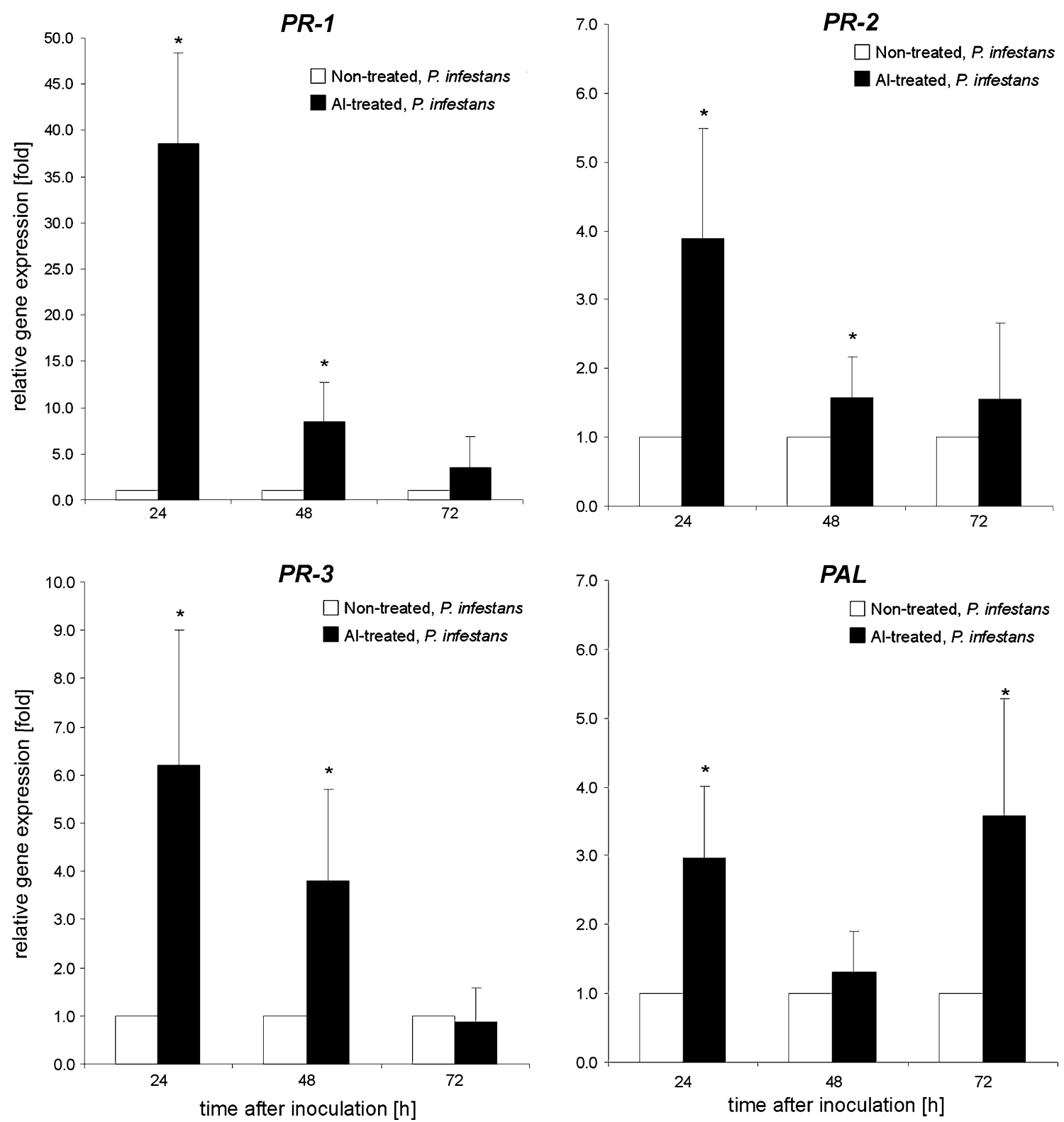

Fig. 8 The effect of pretreatment with aluminum followed by challenge inoculation with $P$. infestans on $P R-1, P R-2, P R-3$ and $P A L$ gene expression in potato leaves. The qRT-PCR analyses of $P R s$ and

attack. It was demonstrated earlier that NO formation is implicated in the mechanism of distal signaling (Gaupels et al. 2008). Piterková et al. (2009) presented evidence that the transmission of a systemic response throughout the tomato plant was related to an enhanced NO formation in distal, non-inoculated leaves. Moreover, production of NO involving the vascular tissue and neighboring cells was assigned to signaling during plant response to salinity, heavy metals and defense-related compounds (Requena et al. 2005; Valderrama et al. 2007; Gaupels et al. 2008; Arasimowicz-Jelonek et al. 2012).

$P A L$ were performed at 24,48 and $72 \mathrm{~h}$ after challenge inoculation. Asterisks indicate values that differ significantly from non-treated, $P$. infestans inoculated leaves at $P<0.05, n=3$

Impact of $\mathrm{Al}$ on $\mathrm{NO}$ mediated $\mathrm{SNO}$ formation in potato leaves

Considering an augmented NO production detected in potato leaves we next focused on the examination of NO might be converted into SNO storage. Our results revealed that an enhanced NO synthesis found in non-aluminum treated parts of potato was accompanied by a significant rise in the SNO pool, which was evidenced by both chemiluminescence and immunohistochemical methods. SNOs are formed by the covalent attachment of NO to a 


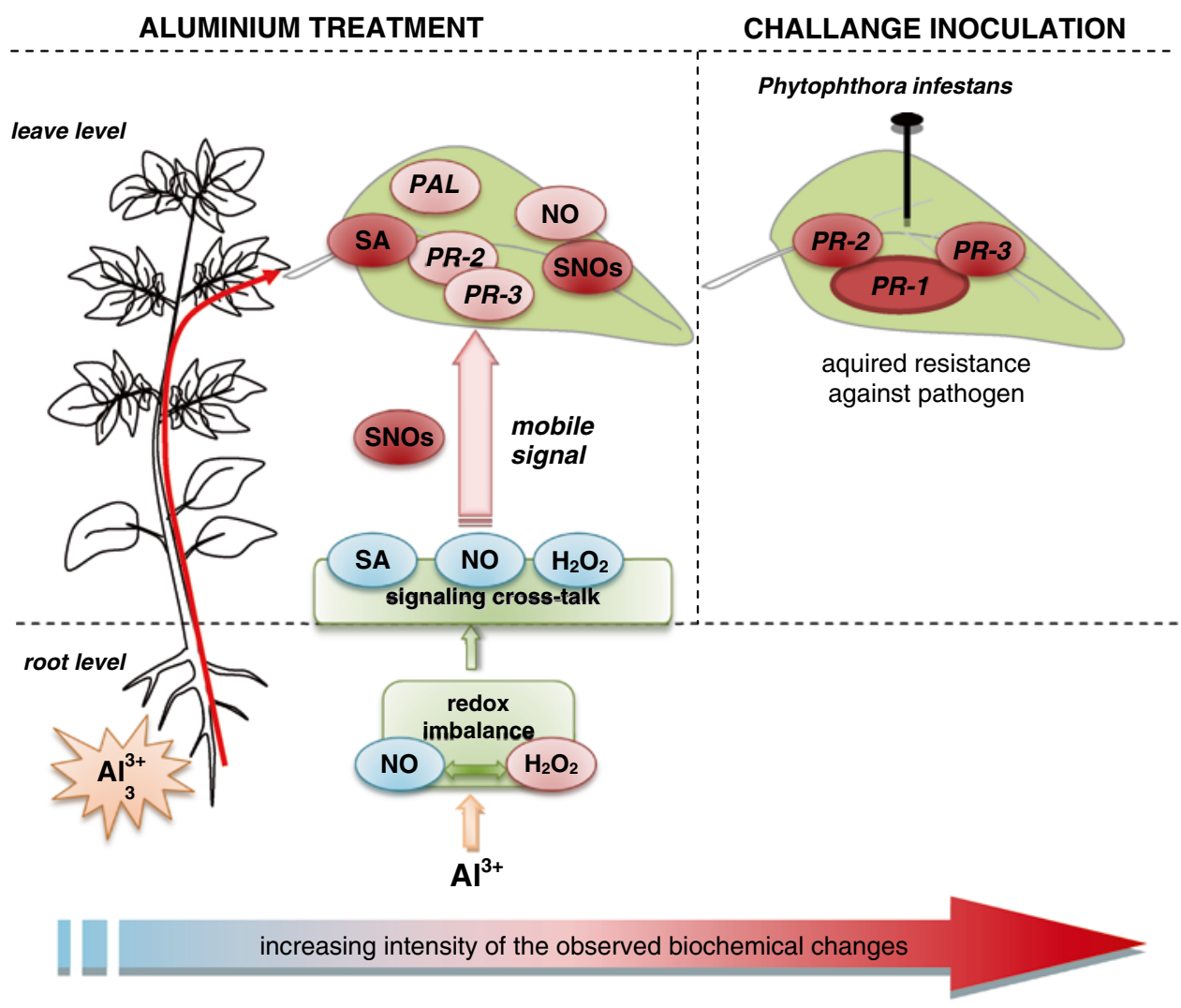

Fig. 9 The proposed mechanism of Al induced cross-resistance of potato to $P$. infestans, in which moderate $\mathrm{Al}$ stress triggered changes in short-term biochemical imprint in distal potato leaves, facilitating effective defense responses against a subsequent pathogen attack. First, plant pretreatment with $\mathrm{Al}$ at the root level provoked redox imbalance manifested in $\mathrm{H}_{2} \mathrm{O}_{2}$ overproduction and diminished $\mathrm{NO}$ synthesis. These local changes might create a redox background for distal NO and SA-dependent signal generation. The complex regula-

protein and non-protein thiols. The S-nitrosylation reaction is a rapid and reversible redox-based protein modification, facilitating a rapid transmission of the NO message into a physiological response. Moreover, changes in the cellular pool of SNOs may determine the fate of plant immunity (Yu et al. 2012). It was recently stated by us that potato leaves exposed to SAR inducers showed a rise in NO generation in cooperation with a reversible abundance of the SNO pool (Floryszak-Wieczorek et al. 2012). Based on BABA-induced events it was stated that coding the NO message in SNO storage at a relatively low threshold together with histone $H 2 B$ up-regulation created a shortterm imprint activation facilitating acquired resistance of potato to $P$. infestans.

To assess whether the SNO level differed in various potato organs we measured the concentration of SNOs at $24 \mathrm{~h}$ after Al root uptake. The SNO level was strikingly reduced in roots, while in contrast it increased in potato stems and systemic leaves when compared with the non-Al-treated potato tory networks facilitated systemic activation of $\mathrm{Al}$ stress responses engaged in the biochemical imprint linked to the coding of NO message in reversible SNO storage. Finally, signal amplification leading to potato resistance manifested in distal leaves of Al-treated plants was related to expression of SA-mediated defense genes (PRs and $P A L)$ early after contact with a challenging pathogen and to subsequent disease limitation

plant. We need to stress here a relatively high level of SNOs in potato stems in view of the transport function of SNOs, or mainly GSNO as a potential systemic resistance signal moving through the vascular system. In confirmation, the immunohistochemical approach revealed an abundant GSNO accumulation in the main vein of potato systemic leaves after a previous exposure to $\mathrm{Al}$ root uptake.

Fifteen years ago, it was proposed for the first time that GSNO might serve as a long-distance phloem-mobile signal for SAR creation (Durner and Klessig 1999). The inability of Arabidopsis to accumulate SNOs correlated with the impairment of SAR establishment in the plants overexpressing reductase of GSNO, both in local and systemic leaves, was documented by Rusterucci et al. (2007). What is more, there is evidence that NO itself might act as a priming-active molecule to induce systemic acclimation against salt stress (Tanou et al. 2009).

To verify if GSNOR controls SNO levels in potato pretreated with $\mathrm{Al}$ we measured the activity of this enzyme 
regulated in the NO system by the breakdown of GSNO and $S$-nitrosylated proteins. Aluminum evoked an intensified NO generation in systemic potato leaves, linked to the abundant formation of SNOs and up-regulation of GSNOR activity. The level of GSNOR activity in systemic leaves did not closely interfere with the SNO level, but correlated with SAR establishment in Al-induced potato plants.

The emerging evidence suggests that cellular SNOs are precisely controlled by NO synthesis and GSNO turnover mediated mainly by GSNO reductase (Liu et al. 2001). Moreover, GSNOR appears to be a key regulator of systemic defense responses in both wounding and pathogenesis (Espunya et al. 2012). Previously Espunya et al. (2006) documented the localization of GSNOR in the phloem companion cells and xylem parenchyma in Arabidopsis plants and showed a more abundant GSNOR activity in the vascular system of plants overexpressing GSNOR both in local and systemic leaves.

However, there is no doubt that GSNO has an important effect for defense or acclimation response in plants, while there are disagreements how GSNOR-governs SNO concentrations, which are able to manipulate the acquisition of resistance. Analyses of GSNOR knock-out plants displayed elevated global SNOs levels and these plants were compromised in non-host and R-gene resistance (Feechan et al. 2005), furthermore were abolished for thermotolerance and failed to grow and develop (Lee et al. 2008).

Exploring the role of denitrosylation in plant resistance it should be noted that GSNOR is mainly involved in the breakdown of GSNO and currently information is also lacking on other cellular specific reductases or lyases acting on protein SNOs (Liu et al. 2001; Malik et al. 2011). Recently it was proposed that the pool of SNOs governed by AtGSNOR1 increases during the development of plant disease resistance, but beyond a certain threshold level of SNOs both SA synthesis, SABP3 function and NPR1 activity are diminished, which negatively regulates the establishment of plant immunity (Malik et al. 2011; Yu et al. 2012).

\section{Aluminum promoted protection to $P$. infestans}

The present study provides new data regarding the effect of $\mathrm{Al}$ on plant organisms, since we found that plant root pre-exposure to aluminum diminished late blight disease symptoms on potato leaves. It needs to be emphasized here that it was correlated with a strong up-regulation of $P R-1$ in leaves early $(24 \mathrm{~h})$ after the challenge inoculation of Al-pretreated plants. Simultaneously, the other analyzed defense genes, both $P R-2$ and $P R-3$, were also expressed at a definitely higher level after pathogen inoculation in comparison with Al-non-treated plants. The markedly faster and stronger defense responses upon $P$. infestans challenge in Al-exposed potato suggests that aluminum induced changes in the short-term biochemical imprint in potato leaves involving reversible $S$-nitrosylated protein accumulation.

There is an increasing body of evidence that induced or primed plants display a unique state of an enhanced capacity to mobilize faster and more potent defense responses to a subsequent abiotic or biotic stress (Floryszak-Wieczorek et al. 2012). For example, $\beta$-aminobutyric acid (BABA) treatment, a non-protein amino acid with a high potential as a priming agent, leads to an induction of $P R$ gene expression at a much lower level than the one noted upon future contact with a challenging pathogen (Slaughter et al. 2012). Although priming is well established in relation to biotic stress, the analogous phenomenon under abiotic stress conditions, leading to a hardening or acclimation process, is poorly characterized (Molassiotis et al. 2010). Ton et al. (2005) showed that treatment with BABA triggered tolerance to salt stress by an augmented expression of ABAdependent defenses.

In our experimental approach previous aluminum stress triggered up-regulation of $P R-1$ local in root and systemic in leaves. Only when the second biotic stress occurred we found an amplified defense response tuned with a 35 -fold increase in $P R-1$ expression when compared with nontreated inoculated plants.

Several lines of experimental data have shown that aluminum toxicity as the important growth limiting factor depends on its dose and is closely related to $\mathrm{Al}$ mobilization in soil promoted by low $\mathrm{pH}$ and acid rains. Our results revealed a new effect of $\mathrm{Al}$ potato root exposure on an enhanced resistance to a biotic factor (Fig. 9). It worth pointing that long-term responses are not directly caused by $\mathrm{Al}$, but might rather be a consequence of numerous other $\mathrm{Al}$ related biochemical and physiological processes, they might be more puzzling than short-term studies in determining the primary effect of Al. Based on this statement we evidenced that $\mathrm{Al}$ treatment directly conditioned the potato plant to express defenses rapidly upon $P$. infestans challenge.

Acknowledgments This work was supported by funds from Ministry of Science and Higher Education (Project No. N N310 040839).

Open Access This article is distributed under the terms of the Creative Commons Attribution License which permits any use, distribution, and reproduction in any medium, provided the original author(s) and the source are credited.

\section{References}

Abeles F, Forrence L (1970) Temporal and hormonal control of $\beta$-1,3glucanase in Phaseolus vulgaris L. Plant Physiol 45:395-400

Achuo EA, Prinsen E, Höfte M (2006) Influence of drought, salt stress and abscisic acid on the resistance of tomato to Botrytis cinerea and Oidium neolycopersici. Plant Pathol 55:178-186 
Alexieva V, Sergiev I, Mapelli S, Karanov E (2001) The effect of drought and ultraviolet radiation on growth and stress markers in pea and wheat. Plant Cell Environ 24:1337-1344

Arasimowicz-Jelonek M, Floryszak-Wieczorek J, Deckert J, Rucińska-Sobkowiak R, Gzyl J, Pawlak-Sprada S, Abramowski D, Jelonek T, Gwóźdź EA (2012) Nitric oxide implication in cadmium-induced programmed cell death in roots and signaling response of yellow lupine plants. Plant Physiol Biochem 58:124-134

Asselbergh B, De Vleesschauwer D, Höfte M (2008) Global switches and fine-tuning: ABA modulates plant pathogen defense. Mol Plant Microbe Interact 21:709-719

Barceló J, Poschenrieder C (2002) Fast root growth responses, root exudates and internal detoxification as clues to the mechanisms of aluminum toxicity and resistance: a review. Environ Exp Bot 48:75-92

Barroso JB, Corpas FJ, Carreras A, Rodriguez-Serrano M, Esteban F, Fernandez-Ocana A, Chaki M, Romero-Puertas MC, Valderrama R, Sandalio LM, del Rio LA (2006) Localization of $S$-nitrosoglutathione and expression of $S$-nitrosoglutathione reductase in pea plants under cadmium stress. J Exp Bot 57:1785-1793

Becana M, Aparicio-Tejo P, Irigoyen JJ, Sanchez-Diaz M (1986) Some enzymes of hydrogen peroxide metabolism in leaves and root nodules of Medicago sativa. Plant Physiol 82:1169-1171

Bowler C, Fluhr R (2000) The role of calcium and activated oxygens as signals for controlling cross-tolerance. Trends Plant Sci 5:241-246

Bradford MM (1976) A rapid and sensitive method for the quantification of microgram quantities of protein utilizing the principle of protein-dye binding. Anal Biochem 72:248-254

Capiati DA, País SM, Téllez-Iñón MT (2006) Wounding increases salt tolerance in tomato plants: evidence on the participation of calmodulin-like activities in cross-tolerance signaling. J Exp Bot 57:2391-2400

Chamnongpol S, Willekens H, Moeder W, Langebartels C, Sandermann H Jr, Van Montagu M, Inzé D, van Camp W (1998) Defense activation and enhanced pathogen tolerance induced by $\mathrm{H}_{2} \mathrm{O}_{2}$ in transgenic tobacco. Proc Natl Acad Sci USA 95:5818-5823

Chandran D, Sharopova N, Ivashuta S, Gantt JS, Vandenbosch KA, Samac DA (2008) Transcriptome profiling identified novel genes associated with aluminium toxicity, resistance and tolerance in Medicago truncatula. Planta 228:151-166

Chmielowska J, Veloso J, Gutiérrez J, Silvar C, Díaz J (2010) Crossprotection of pepper plants stressed by copper against a vascular pathogen is accompanied by the induction of a defence response. Plant Sci 178:176-182

Corpas FJ, Chaki M, Fernández-Ocaña A, Valderrama R, Palma JM, Carreras A, Begara-Morales JC, Airaki M, Río LA, Barroso JB (2008) Metabolism of reactive nitrogen species in pea plants under abiotic stress conditions. Plant Cell Physiol 49: $1711-1722$

Derckel JP, Legendre L, Audran JC, Haye B, Lambert B (1996) Chitinases of the grapevine (Vitis vinifera L.): five isoforms induced in leaves by salicylic acid are constitutively expressed in other tissues. Plant Sci 19:31-37

Doncheva S, Amenos M, Poschenrieder C, Barcelo J (2005) Root cell patterning: a primary target for aluminium toxicity in maize. $\mathrm{J}$ Exp Bot 56:1213-1220

Durner J, Klessig DF (1999) Nitric oxide as a signal in plants. Curr Opin Plant Biol 2:369-474

Espunya MC, Diaz M, Moreno-Romero J, Martinez MC (2006) Modification of intercellular levels of glutathione-dependent formaldehyde dehydrogenase alters glutathione homeostasis and root development. Plant Cell Environ 29:1002-1011

Espunya MC, De Michele R, Gomez-Cadenas A, Martinez MC (2012) S-Nitrosoglutathione is a component of wound- and salicylic acid-induced systemic responses in Arabidopsis thaliana. J Exp Bot 63:3219-3227

Feechan A, Kwon E, Yun BW, Wang Y, Pallas JA, Loake GJ (2005) A central role for $S$-nitrosothiols in plant disease resistance. Proc Natl Acad Sci USA 102:8054-8059

Floryszak-Wieczorek J (2000) Effect of Phytophthora infestans on the activity of oxygen scavenging enzymes in leaves of different potato genotypes. Phytopathol Pol 19:147-155

Floryszak-Wieczorek J, Arasimowicz-Jelonek M, Milczarek G, Janus L, Pawlak-Sprada S, Abramowski D, Deckert J, Billert H (2012) Nitric oxide-mediated stress imprint in potato as an effect of exposure to a priming agent. Mol Plant Microbe Interact 25:1469-1477

Gaupels F, Furch ACU, Will T, Mur LAJ, Kogel KH, Bel AJE (2008) Nitric oxide generation in Vicia faba phloem cells reveals them to be sensitive detectors as well as possible systemic transducers of stress signals. New Phytol 178:634-646

Gong M, Chen B, Li Z, Guo L (2001) Heat-shock-induced cross adaptation to heat, chilling, drought and salt stress in maize seedlings and involvement of $\mathrm{H}_{2} \mathrm{O}_{2}$. J Plant Physiol 158:1125-1130

Hong JK, Hwang BK (2005) Induction of enhanced disease resistance and oxidative stress tolerance by overexpression of pepper basic PR-1 gene in Arabidopsis. Physiol Plant 124:267-277

Illes P, Schlicht M, Pavlovkin J, Lichtscheidl I, Baluska F, Ovecka M (2006) Aluminium toxicity in plants: internalization of aluminium into cells of the transition zone in Arabidopsis apices related to changes in plasma membrane potential, endosomal behaviour, and nitric oxide production. J Exp Bot 57:4201-4213

Lee U, Wie C, Fernandez BO, Feelisch M, Vierling E (2008) Modulation of nitrosative stress by $S$-nitrosoglutathione reductase is critical for thermotolerance and plant growth in Arabidopsis. Plant Cell 20:786-802

Lim MH, Xu D, Lippard SJ (2006) Visualization of nitric oxide in living cells by a copper-based fluorescent probe. Nat Chem Biol 2:375-380

Liu L, Hausladen A, Zeng M, Que L, Heitman J, Stamler JS (2001) A metabolic enzyme for $S$-nitrosothiol conserved from bacteria to humans. Nature 410:490-494

Liu J, Luo X, Shaff J, Liang C, Jia X, Li Z, Magalhaes J, Kochian LV (2012) A promoter-swap strategy between the AtALMT and AtMATE genes increased Arabidopsis aluminum resistance and improved carbon-use efficiency for aluminum resistance. Plant $\mathbf{J}$ 71:327-337

Lotan T, Ori N, Fluhr R (1989) Pathogenesis-related proteins are developmentally regulated in tobacco flowers. Plant Cell $1: 881-887$

Malamy J, Klessig DF (1992) Salicylic acid and plant disease resistance. Plant J 2:643-654

Malik SI, Hussain A, Yun BW, Spoel SH, Loake GJ (2011) GSNORmediated de-nitrosylation in plant defence response. Plant Sci 181:540-544

Mao C, Yi K, Yang L, Zheng B, Wu Y, Liu F, Wu P (2004) Identification of aluminium-regulated genes by cDNA-AFLP in rice (Oryza sativa $\mathrm{L}$.): aluminium-regulated genes for the metabolism of cell wall components. J Exp Bot 55:137-143

Molassiotis A, Tanou G, Diamantidis G (2010) NO says more than 'YES' to salt tolerance Salt priming and systemic nitric oxide signaling in plants. Plant Signal Behav 5:209-212

Moreau M, Lindermayr C, Durner J, Klessig DF (2010) NO synthesis and signaling in plants-where do we stand? Physiol Plant 138:372-383

Mullineaux P, Ball L, Escobar C, Karpinska B, Creissen G, Karpinski S (2000) Are diverse signalling pathways integrated in the regulation of Arabidopsis antioxidant defence gene expression in response to excess excitation energy? Philos Trans R Soc Lond B Biol Sci 335:1531-1540 
Panda SK, Yamamoto Y, Kondo H, Matsumoto H (2008) Mitochondrial alterations related to programmed cell death in tobacco cells under aluminium stress. C R Biol 331:597-610

Pastori GM, Foyer CH (2002) Common components, networks, and pathways of cross-tolerance to stress. The central role of "redox" and abscisic acid-mediated controls. Plant Physiol 129:460-468

Petrov VD, Van Breusegem F (2012) Hydrogen peroxide-a central hub for information flow in plant cells. AoB Plants 2012, pls014

Pfaffl MW (2004) Relative quantification. Chapter in: Real-time PCR. International University Line, pp 63-82

Piterková J, Petřlvalský M, Luhová L, Mieslerová B, Sedlářová M, Lebeda A (2009) Local and systemic production of nitric oxide in tomato responses to powdery mildew infection. Mol Plant Pathol 10:501-513

Requena ME, Egea-Gilabert C, Candela ME (2005) Nitric oxide generation during the interaction with Phytophthora capsici of two Capsicum annuum varieties showing different degrees of sensitivity. Physiol Plant 24:50-60

Rossel JB, Wilson PB, Hussain D, Woo NS, Gordon MJ, Mewett OP, Howell KA, Whelan J, Kazan K, Pogson BJ (2007) Systemic and intracellular responses to photooxidative stress in Arabidopsis. Plant Cell 19:4091-4110

Rusterucci C, Espunya MC, Diaz M, Chabannes M, Martinez MC (2007) $S$-nitrosoglutathione reductase affords protection against pathogens in Arabidopsis, both locally and systemically. Plant Physiol 143:1282-1292

Ryan PR, Tyerman SD, Sasaki T, Furuichi T, Yamamoto Y, Zhang WH, Delhaize E (2011) The identification of aluminium-resistance genes provides opportunities for enhancing crop production on acid soils. J Exp Bot 62:9-20

Sarowar S, Kim YJ, Kim EN, Kim KD, Hwang BK, Islam R, Shin JS (2005) Overexpression of a pepper basic pathogenesis-related protein 1 gene in tobacco plants enhances resistance to heavy metal and pathogen stresses. Plant Cell Rep 24:216-224

Sharma Y, Léon J, Raskin I, Davis KR (1996) Ozone-induced responses in Arabidopsis thaliana: the role of salicylic acid in the accumulation of defense-related transcripts and induced resistance. Proc Natl Acad Sci USA 93:5099-5104

Slaughter A, Daniel X, Flors V, Luna E, Hohn B, Mauch-Mani B (2012) Descendants of primed Arabidopsis plants exhibit resistance to biotic stress. Plant Physiol 158:835-843

Steinberg CEW (2012) Stress ecology: environmental stress as ecological driving force and key player in evolution. Springer, Berlin

Tanou G, Job C, Rajjou L, Arc E, Belghazi M, Diamantidis G, Molassiotis A, Job D (2009) Proteomics reveals the overlapping roles of hydrogen peroxide and nitric oxide in the acclimation of citrus plants to salinity. Plant J 60:795-804

Tian QY, Sun DH, Zhao MG, Zhang WH (2007) Inhibition of nitric oxide synthase (NOS) underlies aluminum-induced inhibition of root elongation in Hibiscus moscheutos. New Phytol 174:322-331

Tippmann HF, Schlüter U, Collinge DB (2006) Common themes in biotic and abiotic stress signalling in plants. In: da Silva JAT (ed) Floriculture, ornamental and plant biotechnology, vol 3. Global Science Books Ltd, Reston, pp 52-67

Ton J, Jakab G, Toquin V, Flors V, Iavicoli A, Maeder MN, Métraux JP, Mauch-Mani B (2005) Dissecting the $\beta$-aminobutyric acid-induced priming phenomenon in Arabidopsis. Plant Cell 17:987-999

Valderrama R, Corpas FJ, Carreras A, Fernández-Ocaña A, Chaki M, Luque F, Gómez-Rodríguez MV, Colmenero-Varea P, del Río LA, Barroso JB (2007) Nitrosative stress in plants. FEBS Lett 581:453-461

Van Breusegem F, Vranova E, Dat JF, Inze D (2001) The role of active oxygen species in plant signal transduction. Plant Sci 131:405-414

Van Loon LC, Van Strien EA (1999) The families of pathogenesisrelated proteins, their activities, and comparative analysis of PR-1 type proteins. Physiol Mol Plant Pathol 55:85-97

Wiese J, Kranz T, Schubert S (2004) Induction of pathogen resistance in barley by abiotic stress. Plant Biol 6:529-536

Xu FJ, Li G, Jin CW, Liu WJ, Zhang SS, Zhang YS, Lin XY (2012) Aluminum-induced changes in reactive oxygen species accumulation, lipid peroxidation and antioxidant capacity in wheat root tips. Biol Plant 56:89-96

Yalpani N, Leon J, Lawton MA, Raskin I (1993) Pathway of salicylic acid biosynthesis in healthy and virus-inoculated tobacco. Plant Physiol 103:315-321

Yalpani N, Enyedi AJ, León J, Raskin I (1994) Ultraviolet light and ozone stimulate accumulation of salicylic acid, pathogenesis-related proteins and virus resistance in tobacco. Planta 193:372-376

Yamamoto Y, Kobayashi Y, Devi SR, Rikiishi S, Matsumoto H (2003) Oxidative stress triggered by aluminum in plant roots. Plant Soil 255:239-243

Yang ZM, Wang J, Wang SH, Xu LL (2003) Salicylic acid-induced aluminum tolerance by modulation of citrate efflux from roots of Cassia tora L. Planta 217:168-174

Yu M, Yun BW, Spoel SH, Loake GJ (2012) A sleigh ride through the SNO: regulation of plant immune function by protein S-nitrosylation. Curr Opin Plant Biol 15:424-430

Zhao S, Fernald RS (2005) Comprehensive algorithm for quantitative real-time polymerase chain reaction. J Comp Biol 12:1047-1064

Zhou L, Bokhari SA, Dong CJ, Liu JY (2011) Comparative proteomics analysis of the root apoplasts of rice seedlings in response to hydrogen peroxide. PLoS ONE 6:e16723 